\title{
Danuta Urbaniak-Zając, Ewa Kos, Badania jakościowe w pe- dagogice. Wywiad narracyjny i obiektywna hermeneutyka, Wy- dawnictwo Naukowe PWN, Warszawa 2013, s. 304
}

Publikacja stanowi próbę włączenia się w aktualną dyskusję na temat metodologicznych i metodycznych aspektów badań pedagogicznych. Nurt badań jakościowych w pedagogice nie był do niedawna uznawany za wiarygodny i potrzebny. Szukając uzasadnienia dla takiego stosunku pedagogów do metod jakościowych, Danuta Urbaniak-Zając stawia tezę, iż „może był to wyraz tak silnego oddziaływania paradygmatu epistemologicznego (pozytywistycznego czy też neopozytywistycznego modelu nauki), że właściwe mu metody naukowego poznania nie mogły być kwestionowane? Ich podważanie mogło świadczyć jedynie o nienowoczesności lub ekscentryzmie tego, kto podawałby je w wątpliwość" (s. 9). Autorki publikacji podjęły się trudnego, aczkolwiek niezwykle ważnego, zadania „odkłamania” istniejących mitów na temat wykorzystywania metod jakościowych w pedagogice, mitów zakorzenionych w świadomości polskich badaczy i metodologów w obszarze nauk społecznych. Wskazują na niedostateczne, powierzchowne rozumienie tych metod i ,techniczno-warsztatowe ujmowanie metodologii, sprowadzające ją w istocie do metodyki prowadzenia badań" (s. 11). W badaniach pedagogicznych ważna jest umiejętność praktycznego zastosowania danej metody, na równi z teoretycznym uzasadnieniem jej wyboru. Trudność stosowania metod jakościowych wynika często z niewiedzy, braku doświadczenia, błędnej interpretacji założeń oraz niepewności co do rezultatów procesu badawczego. Podjęcie tego tematu przez autorki wydaje się zatem szczególnie uzasadnione wobec wielu niejasności i uproszczeń, fałszywych przekonań i niewłaściwego, praktycznego podejścia do jakościowego badania rzeczywistości edukacyjnej i społecznej.

Struktura publikacji opiera się na pięciu rozdziałach. Pierwszy z nich, zatytułowany Jakościowa orientacja w badaniach pedagogicznych zawiera pre- 
zentację koncepcji badań jakościowych na tle tradycyjnego modelu empirycznych badań ilościowych. Autorka tej części, Danuta Urbaniak-Zając przedstawia krytyczną analizę porównawczą koncepcji badań ilościowych i jakościowych, reprezentowanych przez różnych autorów podręczników do metodologii (W. Zaczyński, H. Muszyński, Z. Zaborowski, R. Wroczyński, A. Kamiński, T. Pilch, I. Lepalczyk, T. Bauman, M. Łobocki). W przejrzysty sposób dokonuje oceny negatywnych skutków stosowania zabiegów statystycznych w procedurze badań ilościowych dla interpretacji rzeczywistości, np. operacjonalizacja zmiennych, standaryzacja, reprezentatywność wyników. Autorka omawia także dwa przeciwstawne paradygmaty modelowych opisów życia społecznego: normatywny i interpretatywny, w perspektywie badań jakościowych. Zwraca uwagę na zróżnicowanie i niejednorodność metod jakościowych, które raczej przypominają labirynt lub mozaikę niż zwartą i uporządkowaną strukturę kryształu. Próbuje zatem poprowadzić czytelnika przez ów labirynt, odwołując się do założeń metodologii konstruktywistycznej i partycypacyjnego paradygmatu w badaniach jakościowych.

W kolejnych rozdziałach znajdujemy ustrukturalizowane omówienie dwóch metod badań jakościowych, opracowanych przez niemieckich socjologów: wywiadu narracyjnego (Fryderyk Schütze) i obiektywnej hermeneutyki (Ulrich Oevermann). Obie metody zobrazowano przez opis dwóch bardzo ciekawych przykładów ich zastosowania w praktycznej działalności badawczej i interpretacji konkretnych danych. Każdy z nich jest treścią oddzielnego rozdziału. Metodę wywiadu narracyjnego charakteryzuje Ewa Kos, natomiast Danuta Urbaniak-Zając zajmuje się metodą (i metodologią) obiektywnej hermeneutyki. Prezentacja podanych metod obejmuje podobne etapy. Na początku czytelnik jest zapoznawany z teoretycznymi założeniami metody. Następnie autorki przechodzą do klarownego objaśnienia sposobu przeprowadzenia procedury badawczej, zasad opracowywania i analizowania uzyskanych wyników badań. Końcowy element charakterystyki to refleksje krytyczne, które obiektywizują podejście poznawcze do każdej z metod i uwrażliwiają czytelnika na ich mankamenty i trudności procesu badawczego.

Wywiad narracyjny jest metodą bardziej znaną wśród polskich badaczy niż obiektywna hermeneutyka. Mimo to, zdaniem Ewy Kos, metoda ta „nie doczekała się w języku polskim tak szczegółowych opracowań, jak na przykład metoda teorii ugruntowanej lub etnometodologia" (s. 91). Autorka poświęca tej metodzie rozdział II i III książki. Opisuje m.in. trzy główne założenia ontologiczne tej metody: 1. „Rzeczywistość społeczna ma charakter procesualny, a jednostka kształtuje własne zachowanie w toku relacji 
ze środowiskiem; 2. Nie wszystkie formy aktywności jednostki są przez nią świadomie konstruowane; 3. Istnieje zasadnicza zgodność (homologia) pomiędzy nieprzygotowaną wcześniej narracją o życiu i jego rzeczywistym przebiegiem" (s. 93). Teksty zawierają szczegółowe informacje na temat przebiegu wywiadu oraz procesu interpretacji danych narracyjnych. Jako przykład autorka podaje fragment własnych badań jakościowych, dotyczących doświadczeń biograficznych kobiet, które odniosły sukces zawodowy. Przedstawia interpretację wywiadu narracyjnego z kobietą, dyrektorem oddziału jednej z firm ubezpieczeniowych.

Druga autorka, Danuta Urbaniak-Zając, definiuje rzeczowy przedmiot zainteresowań obiektywnej hermeneutyki jako „społeczne działania człowieka, przebiegające w procesach interakcji" (s. 174). Teoretycznym przedmiotem jest "ponadindywidualny poziom działania człowieka”, na który składają się: „obiektywne struktury znaczenia i ukryte (latentne) struktury sensu" (s. 175). Autorka wyjaśnia również najważniejsze pojęcia charakterystyczne dla tej metody, np. tekst i protokół, analizę sekwencji, eksperymenty myślowe, generalizację struktury przypadku. Podaje interesujący przykład konkretnego badania jakościowego, przeprowadzonego wśród studentów pedagogiki, gdzie badano „obraz zawodu pedagoga, budujący się w świadomości studentów w trakcie kształcenia akademickiego, rekonstruowany na podstawie wypowiedzi studentów i traktowany jako odzwierciedlenie treści przekazywanych w procesie kształcenia" (s. 224).

Jasny i spójny sposób przekazu, a także akcentowanie głównych wątków sprzyjają lekturze i zrozumieniu specyfiki prezentowanych metod. Dostarczają też inspirujących doświadczeń, skłaniają do krytycznej refleksji nad własnym warsztatem badawczym. Czytelnik ma okazję, by nie tylko czerpać wiedzę teoretyczna i praktyczną, niezbędną do poznania obu metod. Lektura książki pobudza przede wszystkim do przemyśleń i twórczych poszukiwań w obszarze badań pedagogicznych. Dodatkowym atutem jest przejrzysta szata graficzna i przemyślany układ pracy. W tekstach znajdują się wyróżnienia treści kluczowych i końcowe podsumowania, bloki rozszerzające. Całość opatrzona jest bogatą bibliografią oraz załącznikiem - transkrypcją narracji. Publikacja jest zatem wartościową, ciekawą propozycją dla pedagogów zainteresowanych eksploracją rzeczywistości społecznej i edukacyjnej z wykorzystaniem metod jakościowych. 